\title{
CHALLENGES IN PROMOTING ECONOMIC GROWTH OF GHANA THROUGH VALUE ADDED EXPORTS

\author{
Isaac Ibrahim ${ }^{1}$, Haiyun Liu ${ }^{2}$
}

\begin{abstract}
Ghana is endowed with natural resources such as gold, cocoa, crude oil, and other factor endowments that gives the country a comparative advantage in trade. Ghana, a low-middle income country, is the second largest producer of gold in Africa and $11^{\text {th }}$ in the world, as well as the second largest exporter of cocoa in the world. With all the factor endowments and export potential however, the country exports basically raw materials with little value addition and therefore is deprived of the full benefits accruing to trade and exports.

This paper employs an empirical method and applies the Ricardian Model of Comparative Advantage using available secondary data to explore the importance of exports to the economic growth of the country and certain challenges of value addition. The findings show that exports promote economic growth as well as that value addition can be beneficial in earnings and needs government attention in following the recommendations therein.
\end{abstract}

JEL Classification Numbers: F1, F140, Q17; DOI: http://dx.doi.org/10.12955/cbup.v6.1155

Keywords: Comparative Advantage, Export led, International trade, Value Added, Ghana, Challenges

\section{Introduction}

According to David Ricardo (1817), countries differ in their factor endowments or technologies that gives them comparative advantage. Located in West Africa, Ghana is one of the most promising economies in Sub-Saharan Africa (SSA). Ghana's comparative advantage lies in its natural factor endowments mainly gold, cocoa, crude oil, cashews, manganese and timber. In particular, gold and cocoa form a huge percentage of all Ghanaian exports, with Ghana ranking $11^{\text {th }}$ in gold exports and $2^{\text {nd }}$ in cocoa production worldwide. Gold however dominates export earnings of the country. As of 2016, Ghana ranked $64^{\text {th }}$ in the world in terms of exports with exports totaling 10.5 billion (bn) United States Dollars (USD) for that year. Currently, Switzerland, United Arab Emirates (UAE), China, Vietnam, India and China are some of the top destinations for Ghanaian exports.

According to the World Bank (WB), Ghanaian exports have been declining over the last five years at a rate of $-100 \%$ per annum from 14.6 bn USD in 2011 to 10.5 bn USD in 2016. In terms of general economic outlook, GDP for Ghana was 42.6bn USD in 2016.

In this paper, we examine Ghanaian exports, challenges in adding value and make recommendations on value that can be added in order to boost exports and economic growth.

Problem Statement

Factor endowments; ceteris paribus, are expected to boost economic growth through exports as submitted by the theory of comparative advantage. In recent times, Ghana has had a stable political environment and is a conducive business and investment destination. Coupled with factor endowments such as gold and cocoa, the country is expected to harness synergy to boost exports and accelerate economic growth. However, it is experiencing declining exports and does not reap the full benefits of trade, as raw materials constitute the majority of exports. What are the challenges? What can be done to reverse the situation? How can the economy take full advantage of comparative advantage? This is the problem that this study addresses

Aim of Study

The aim of this paper is to take a brief look at Ghanaian exports, outline challenges to value addition and make recommendations on how to gain from comparative advantage in natural factor endowments such as gold, cocoa, timber, etc; to promote economic growth through adding value to the traditional raw materials that are exported. This study aims to do this by employing the theory of comparative advantage and empirical/theoretical data in analysis of the phenomena.

\footnotetext{
${ }^{1}$ School of Economics, Huazhong University of Science and Technology, Wuhan China, safarilioncrimson@yahoo.ca

${ }^{2}$ School of Economics, Huazhong University of Science and Technology, Wuhan China, I201522128@hust.edu.cn
} 


\section{Literature Review}

\section{Trade Openness and Economic Growth}

The economic theory of comparative advantage postulates that nations should produce and export goods with relatively lower opportunity cost as per David Ricardo (1817). According to Wacziarg and Welch (2003), economies that open up to trade will experience growth in both investment and GDP. The export led growth hypothesis states that international trade propels specialization and division of labour in production processes of export commodities, foreign technological know-how adoption, as well as economies of scale that can lead to economic growth (Helpman \& Krugman, 1985). Edwards (1992) in his study writes that resource re-allocation to efficient sectors of trade and adoption of more advanced production processes and know-how will cause economy wide spill-overs. Authors such as Lucas (1988) agrees with this assertion. According to Giles and Williams (2000a, 2000b), export sectors benefiting from such spillovers will experience sectorial growth and improve the economy as a whole. As submitted by Chenery and Strout (1966), foreign exchange build-up and improvement in balance of payment conditions can accrue from export expansion; and importation of needed goods and production technologies are enhanced

Exports, Diversification and Value Addition

Esfahani (1991) writes that where there exist foreign market entry barriers, exports are particularly useful. Several studies documenting the relationship between exports and economic growth in developing countries; including those by Ram (1985), Jung and Marshal (1985), Chow (1987), Levin and Raut (1997) establish a positive correlation between the two variables. Using cross -country analysis, Michaely (1977) writes that exports contribute to development in developing countries.

Greenway, Morgan and Wright (1999) in their studies write about the essence of composition of a basket of exports. In terms of export commodities and export earnings, Thirwall (1995) submits that $80 \%$ of all export earnings of African countries are from primary raw commodities with prices of these commodities declining at $0.5 \%$ annually. Export of primary products, resultant vulnerability to external shocks, deteriorating prices as well as their terms of trade leads to worsening terms of trade of developing economies as submitted by Sakar (1986). Srinivasan and Bhagwati (2001) state that manufactures are less vulnerable to external shocks and cyclical change. Authors such as Chenery (1979) and Agosin (2017) are of the view that vertical diversification of exports from raw or primary commodities to manufactured goods is essential in promoting economic growth through exports. According to Michaely (1962), export earnings can help in the long run to stabilize export earnings. Rodrik (2006) writes further that as long as export commodities are composed of low value, diversification as well as specialization will not lead to economic growth. Examining the relationship between export diversification and economic growth from 1962 to 2000, Hesse (2008) found that whereas developed countries perform better with specialization of exports, export diversification benefited developing economies.

\section{Data and Methodology}

This study uses the theory of comparative advantage to explain how Ghana's resource endowments can give the economy a comparative edge and boost economic growth through exports. Empirical data is imported from the World Bank country database, International Monetary Fund, government of Ghana policy documents, Central Intelligence Agency (CIA) World Fact book and other sources to provide exposition of Ghana exports, challenges in value adding and recommendations on transformation from primary to manufactured goods.

The theory of comparative advantage

The theory of comparative advantage by David Ricardo (1817); the foundation of trade submits that economies around the world differ in terms of their resource endowments and/or technological knowhow; such as Ghanaian cocoa production and American plane manufacturing technology. Further, countries face an opportunity cost of production due to resource constraints. An economy has comparative advantage in producing a good over other countries if it can do so at a relatively lower opportunity cost. Gains from trade will arise if the economy with a comparative advantage specializes in producing that particular good and trades it for other goods for which it has a comparative disadvantage. Consider an example of two countries: Ghana and China. Both produce two goods; cocoa and clothes. Assume China requires 40 hours of labour for 1 unit of cocoa and 30 hours for 1 unit of 
clothes, while Ghana requires 50 hours for cocoa and 70 hours for clothes, respectively. China is more efficient in producing both cocoa and clothes, as it takes less man hours than Ghana. Without trade, Ghana would need 50 man-hours to produce one unit of cocoa or 50/70 unit of clothes, whereas China would need 40 man-hours to produce one unit of cocoa or 40/30 units of clothes. Hence, Ghana will need 120 man-hours in the production and consumption of a unit of both, while China on the other hand will need 70 man-hours for both. Thus, Ghana has a comparative advantage in cocoa production whereas China's efficiency lies in clothes. With both countries specializing in goods they have a comparative advantage in, world output increases as Ghana can now use 120 hours of labour to produce 2.4 units of cocoa, whereas China can produce 2.3 units of clothes with 70 hours of labour. Furthermore, both countries with their ratios of 50/70 and 40/30 units for clothing production can benefit from the consumption of a unit each of cocoa and clothe, 0 to 0.4 units of cocoa and 0.3 units of clothes remaining to be exported. It thus pays if Ghana specializes in producing cocoa and, China in clothing.

The Ricardian Model of Comparative Advantage and its application

In the Ricardian Model, the following assumptions are made: There are only two countries producing only two commodities; Ghana produces cocoa (denoted by $C$ ) and China produces clothes (denoted by $K$ ). Labour (L) is the only factor of production and it is only domestically mobile. Further, labour force (amount of labour required) in each country is denoted by LF. If we treat each country independently, the total labour required for cocoa and clothing in Ghana can be denoted by $a L F C$ and $a L F K$ respectively, with quantities $(\mathrm{Q})$ of cocoa as $\mathrm{QC}$ and $\mathrm{QK}$ for clothing. The same variables for China are denoted with asterisk (*), meaning $a L F C^{*}$ for labour required for cocoa, $a L F K^{*}$ for clothing, $Q C^{*}$ for quantities $(\mathrm{Q})$ of cocoa and $Q K^{*}$ for quantities $(\mathrm{Q})$ of clothing. Our final assumption is that Ghana is relatively more efficient in producing cocoa: $a L F C / a L F C^{*}<a L F K / a L F K^{*}$, that is Ghana has a lower opportunity cost for cocoa in terms of clothing than China which gives it comparative advantage $\left(a L F C / a l F K<a L F C * / a L F K^{*}\right)$.Without trading, the relative price of cocoa and clothing in both countries will be determined by the relative man-hour cost of the two commodities ( $L L F C / a l F K$ in Ghana and $a L F C^{*} / a L F K^{*}$ in China). If the two countries trade the world price of cocoa denoted by WPC and that of clothing by WPK, will determine the price of the commodities. With this in mind, we can try to determine the relative world supply (lets denote by WRS) or demand (WRD) for both cocoa and clothing by finding the ratio of world supply or demand for cocoa to that of clothing. At the point of equilibrium, the relative world price which is the ratio of world price of cocoa to cloth; WPC/WPK is determined by the relative world supply and world relative demand curves as shown in figure 1.

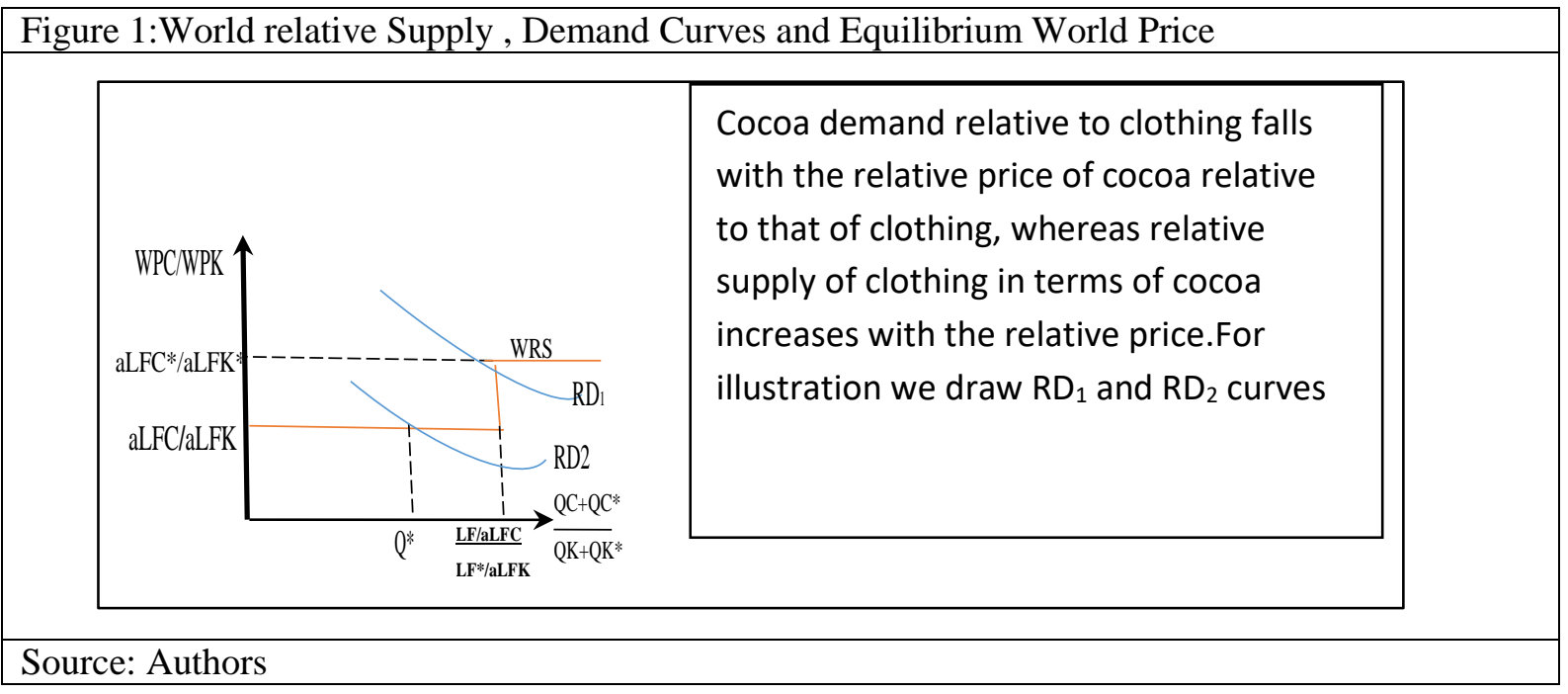

It is assumed that the relative demand curve has a substitution effect decreases in regards to relative price (of clothing). Based on our hypothesis that Ghana has a comparative advantage in cocoa production, the possibilities for relative quantity supplied at a particular price could be several scenarios. First, If $W P C / W P K=a L F C / a L F K<a L F C^{*} / a L F K^{*}$; China will produce clothing as the wage of $W P K^{*} / a L F K^{*}$ in clothing is better than that of cocoa $\left(W P C^{*} / a L F C^{*}\right)$. An indifference in both sectors in Ghana will mean undefined quantity. On the other hand if WPC/WPK is $<a L F C / a L F K<a L F C * / a L F K^{*}$, both countries will produce clothing and supply quantity due to the above reason is zero. Should 
$a L F C / a L F K<W P C / W P K<a L F C * / a L F K^{*}$, Ghana specializes in cocoa whereas China in clothes. Supplied quantity is given as ratio $\underline{L F / a L F C}$ of the total cocoa production to that of clothing.

\section{$L F * / a L F K^{*}$}

Further, if $a L F C / a L F K<a L F C * / a L F K^{*}<W P C / W P K$, both countries will produce cocoa and as the quantity of clothing approaches zero, that of cocoa will be infinite. Finally, if $a L F C / a L F K<$ $a L F C^{*} / a L F K^{*}=W P C / W P K$, Ghana produces cocoa whereas indifference in China will result in relative supply quantity taking an undefined value as shown in figure 1 above. It is worthy to note that Relative price will be unequal so long as there is finite relative demand; $a L F C / a L F K \leqslant P C / W P K \leqslant$ $a L F C * / a L F K^{*}$. Without trade, Ghana has a constraint of production $a L F C Q C+a L F K Q K \leqslant L F$, meaning it can consume $Q C=L F / a L F C$ - $(a L F K / a L F C) Q K$. If Ghana trades with China, Ghana exclusively produces cocoa for which it can export for clothing at a going rate. Ghana's total consumption constraint will now be $a L F C Q C+a L F C(W P C / W P K) Q K \leqslant L F$, whereas its cocoa consumption possibilities (frontier) is $Q C=L / a L F C$ - $(W P K / W P C) Q K$. $\geqslant L F / a L F C$ - $(a L F K / a L F C) / Q K$. We can argue symmetrically for China. Specializing and exporting the good in which it has comparative advantage therefore means more expansion of consumption choices and that consumers in both Ghana and China have a wide range of choices for cocoa and clothing as shown in Figuire 2 below.

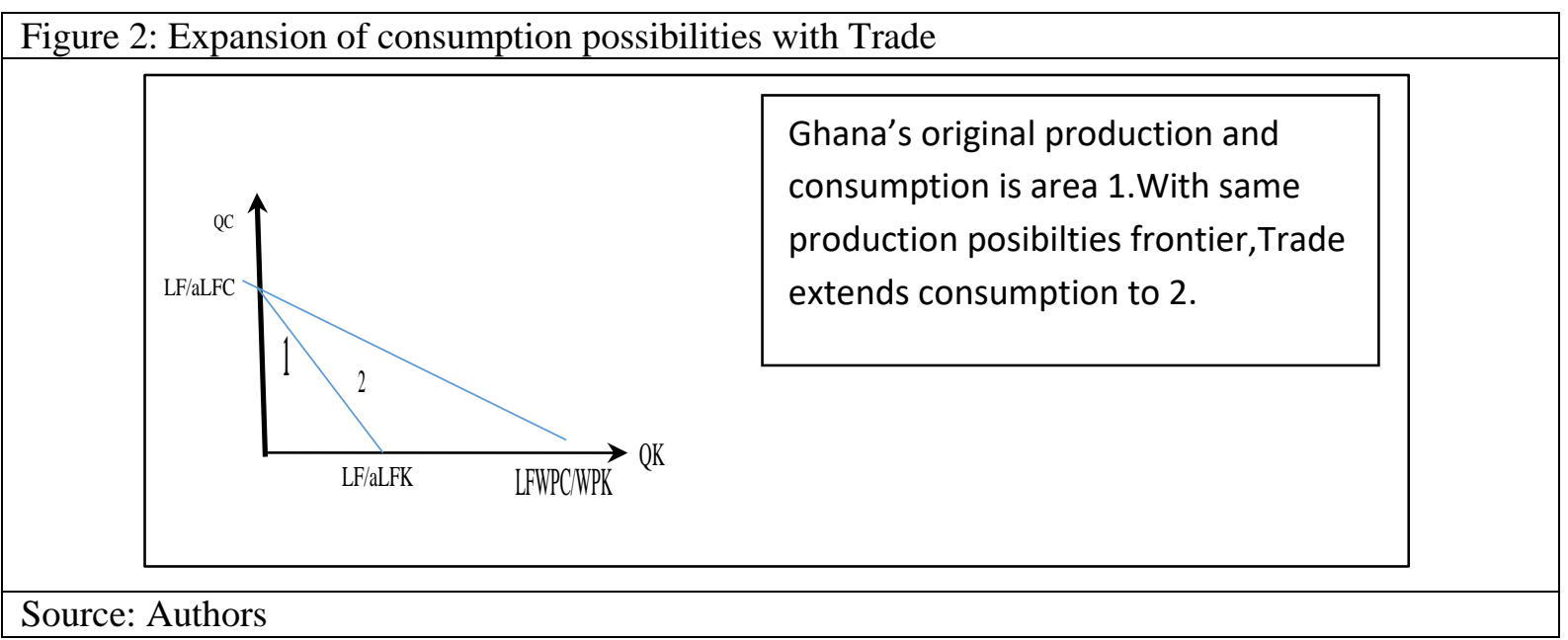

\section{Results and Discussion}

Based on the theory of comparative advantage, Ghana can specialize in producing cocoa and other products for which it has comparative advantage, benefit from scale economies, and export for foreign earnings whilst benefiting from variety. Whereas Ghana has benefited from expansion of consumption possibilities, such as cars, clothing, electronics, and through imports, the same cannot be said for its exports. Ghana's imports currently outweigh exports leading to deficits.

Ghana Exports outlook

Whereas Ghana imports 11 billion (bn) USD, it exports stood at 10.5bn USD as at 2016 with a deficit of 508million(m) USD .Ghana's top 5 export destinations in 2016 were Switzerland (1.87bn USD), India(1.56bn USD), United Arab Emirates (1.43bn USD), China(941m USD), Vietnam (549m USD).Exports were composed of gold (4.43bn USD), cocoa (1.89bn USD), cashews, nuts (987m USD), crude oil (960m USD), timber (367m USD). Generally, the lowest exports were recorded in the $1^{\text {st }}$ quarter of 2003 (565.06m USD) and reaching an all-time high in 2012 first quarter (4118.830m USD). In 2017, exports decreased from $3251.80 \mathrm{~m}$ USD in the $2^{\text {nd }}$ quarter to $2834.11 \mathrm{~m}$ USD in the $3^{\text {rd }}$ quarter. From 2013 to 2017, exports averaged 2032.41m USD. Export data from 2015 to2017 are below in figure 3.

Ghana Primary Exports and deficits

As shown in the figure below, from 1995 to 2016, imports denoted by the red have outweighed exports, and though exports undertook imports in 2011/2012, it was short-lived as they fell below imports again in $2013 / 2014$. 

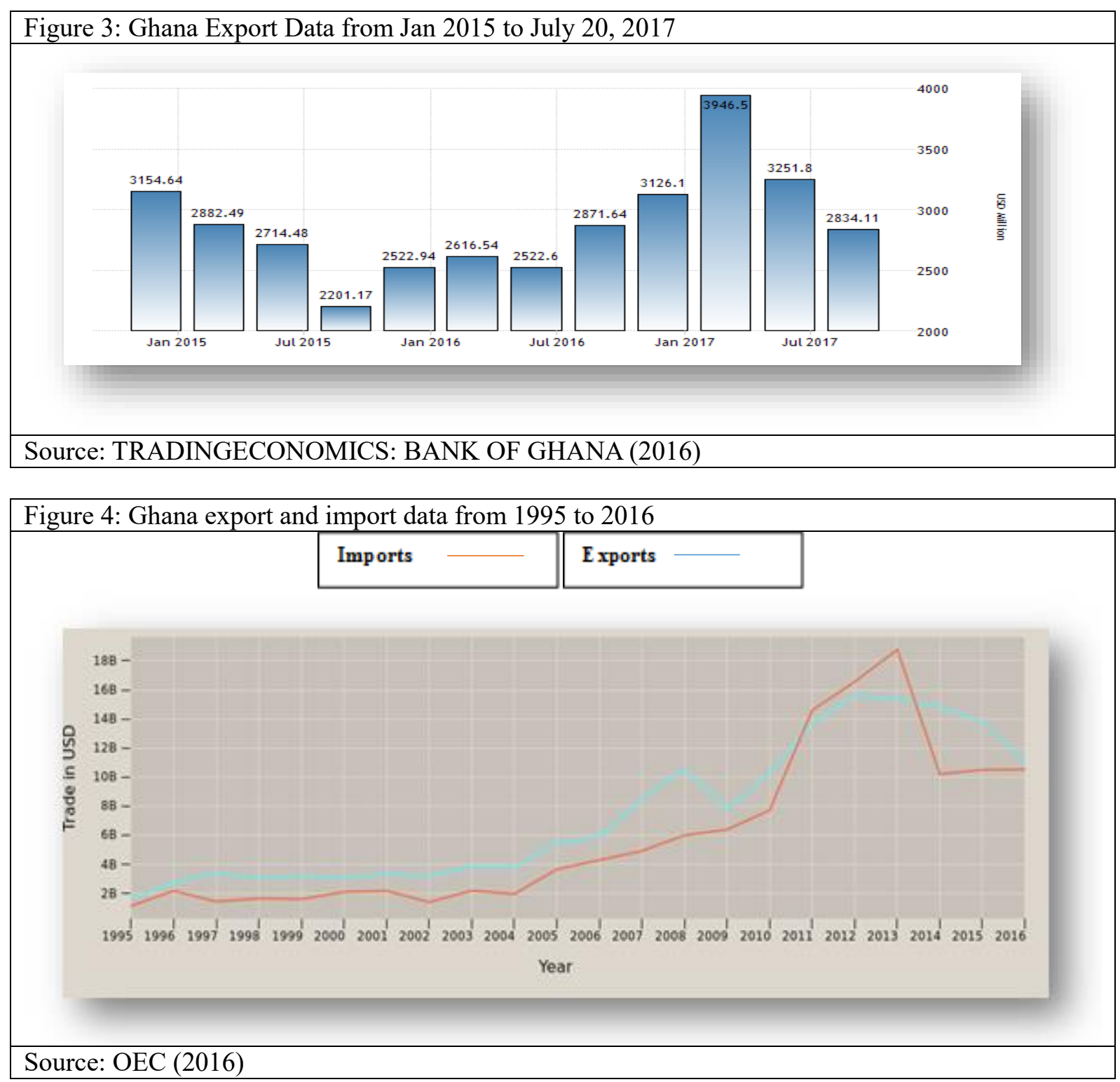

In contradistinction to Ghana's primary exports, it imports manufactured goods of higher value than it exports, including cars ( $\$ 881 \mathrm{~m})$, trucks (481m USD), cement (389m USD), rice (287m USD) and frozen fish (263m USD).Top import destinations are China (4.67bn USD), United States (831m USD), United Kingdom (749m USD), India (712m USD) and the Netherlands (485m USD).The difference between composition and value is notable as well the destinations. China for example is Ghana's $4^{\text {th }}$ export destination of primary raw products, but ranks as its number one import partner. Ghana's sectorial composition according to the CIA World Fact Book is: Agriculture 19.7\%, Industry $25.3 \%$ and Services $59.4 \%$ (2016 estimates). Whereas the share of agriculture has decreased, the growth in the other two sectors have been skewed towards services, and the increase in industry has been towards building; primarily housing rather than manufacturing and value addition. In the face of GDP growth estimated at 120.9bn USD (2016 PPP), and deficit balance of payments, foreign exchange earnings have been boosted by other sources such as individual remittances by citizens abroad rather than on the face value of export earnings. Ghana as of 2016 estimates had a 11.99 million labour force with the agriculture sector employing almost half at $44.7 \%$, services taking second at $40.9 \%$ and industry taking only $14.4 \%$.Labour in industry are mainly employed in mining, lumbering, food processing and cement. As submitted in our literature review the basket of exports matter, and manufactured goods are less affected by external shocks. Given that $60 \%$ of developing country earnings, and $80 \%$ of all African countries export earnings are from exporting primary raw commodities with prices of these commodities declining at $0.5 \%$ annually, as opposed to manufactured, Ghana needs to add value to its exports. This is especially true as gold and cocoa prices continue to fall and fluctuate, and thus, vertical diversification of primary 
products to manufactures is necessary. Ghana has selected and traditional exports of low value with little value added, and with industry growing at $-0.5 \%$ annually, Ghana needs to accelerate its rate of industrialization.

Ghana's industrial outlook and challenges to value addition

Ghana begun its industrialization in the 1960's when it gained independence and with the socialist ideas of the then Nkrumah government, industrialization was state-led with the establishment of state owned enterprises (SOEs). However, the overthrow of the government and many coups that followed led to mismanagement, corruption and collapse of these SOEs that were purported to lead the industrialization drive of the economy. Following some political stability, the International Monetary Fund (IMF) Economic Recovery Programme (ERP) in 1983 sought to revamp the economy and deepen private participation. Many of the remaining inefficient SOEs were privatized as a result. The private sector did not have the capacity to take over such mantle of capitalist transformation and as such industry did not grow. The sector continues to be composed of micro, small and medium scale enterprises (MSMEs) while the number of large scale enterprises are very few. The Government, whilst not leading the industrial drive, does not grant the much needed support and partnership for growth of the industry. One of the strategies of Ghana's vision for 2020 of accelerated economic growth is rapid and aggressive industrialization. However, Ghana's industrialization drive continues to be confronted by problems including: lack of access to funding. Private investment thrives on access to funding and loanable funds. However, not only is such needed support from the government not forthcoming, but accessing loans in Ghana for investment can be a difficult task in terms of collateral security and huge interest. Poor infrastructure; poor roads mean the linkage between agriculture and industry is broken, as most produce raw materials that cannot be easily transported to subsequent factories or markets. In addition, the existing rail network is near collapse as well as the much-needed factory buildings and equipment for value adding are not available. Finally, Energy problems; Ghana relies heavily on hydroelectric power and over the years the main Akosombo Dam, which relies primarily on water has been unreliable. The economy has experienced energy crises and load shading, which led existing industries to lay-off or close whilst discouraging future investment.

\section{Conclusion and Recommendations on Value addition}

Conclusion

In this study we took a brief look at comparative advantage and in applying the Ricardian Model. We found that countries are better off when they specialize in the goods in which they have comparative advantage. Ghana's comparative advantage lies primarily in cocoa and gold production. We also found out Ghana's exports are made up of primary products in line with studies by Thirwall (1995); with low value which does not benefit much in trade in line with Rodrik (2006). Diversification though necessary, industrialization hence manufacturing, and value addition is required; the absence of which will not grant the economy of Ghana the full gains of trade in earnings. In review of industrial outlook, we found that the industry sector in Ghana has a $-0.5 \%$ annual growth rate and is fraught with problems that need attention...

Recommendations on Value addition.

The government of Ghana has recently tried to diversify exports by promoting "non-tradition exports". The ultimate goal of the government should be promotion of modern industrialization. The government will do well to draw a clear and implementable industrialization agenda. Following examples of successful economies such as China as well as well seeking investment assistance tailored towards industry will be helpful. Government needs to first; tackle problems facing the sector by promoting government-private partnership and offering the needed subsidies and support. On finance and capital, the state banks such as National Investment Bank (NIB) can provide interest-free and low-interest loans for investment, and fiscal policy should ease the burden of tax for investors. Focus should not only be attracting inward foreign direct investment (IFDI), but rather foreign-domestic, joint ventures to promote technological spill-overs and learning. Hence, foreign capital/technological investment should be the country's priority. The agriculture sector should be modernized by investing in mechanized farming to provide raw materials for industry, as well as produce imported food commodities such as rice and fish, which will ease import burden and release funds for investing in capital goods. Research and Development (R\&D), and investment in laboratories and research stations, restructuring of the 
education system, moving away from the traditional white color degrees to science, technology and modern technical education as well as promoting a spirit of entrepreneurship will change labour force complexion, and promote knowledge generation and innovation. Promoting people for people exchanges, sending citizens overseas to learn in countries such as China and tackling some of problems talked about earlier will also benefit the economy. There is the need to shift from hydroelectricity towards other sources such as thermal, wind, and solar energy to provide stable energy requirements for industries. Infrastructure development should be accelerated; linking roads and railways especially for easy access can promote industrialization and economic growth. Modern information and communication summed in internet access is also essential, and the government will do well to lead the way in adopting these recommendations to accomplish the industrialization agenda of the country. Ghana exports cocoa, but not much processed cocoa product such as chocolates. The gains from trade from our model can only be realized with industrialization and value addition.

\section{References}

Agosin, M. R. (2007). "Export Diversification and Growth in Emerging Economies", Working Paper No. 233, Departamento de Economía, Universidad de Chile.

Chenery, H., B., Strout, A. M. (1966, September). “Foreign Assistance and Economic Development”, The American Economic Review, Volume LVI, Number 4, Part I.

Chenery, H. (1979). Structural Change and Development Policy, New York, Oxford University Press.

Edwards, S. (1992).Trade orientation, distortions and growth in developing countries. Journal of Development Economics 39 , $31-57$.

CIA World Fact Book (2016).Country Publication. Retrieved from_https://www.cia.gov/library/publications/the-worldfactbook/fields/2012.htm

Esfahani, H. (1991). Exports, imports and economic growth in semi-industrialized Countries. Journal of Development Economies 5: 93-116.

Ghana trade. Org (2017) .Ghana top 5 export products. Retrieved from http://ghanatrade.org/export-ghana/

Chow, P.C.Y. (1987). "Causality Between Export Growth and Industrial Development: Empirical Evidence from LDCs," Journal of Development Economics, 26, 55-63.

Glies, J.A., \& Williams C.L. (2000). "Export Led Growth: A Survey of Empirical Literature and Some Non-Causality Results, Part 1" Journal of International Trade and Economic Development, Vol. 9: 261-337.

Greenaway, D.; Morgan. W., Wright .P (1999). “Exports, Export Composition and Growth” Journal of International Trade and Economic Development, Vol. 8: 41-51

Helpman, E., \& Krugman, P. (1985) .Market Structure and Foreign Trade: Increasing Returns, Imperfect Competition and the International Economy. MIT Press, Cambridge.

Hesse, H. (2008). "Export Diversification and Economic Growth”, Working Paper No. 21, Commission on Growth and Development, World Bank, Washington, D.C

Jung, W.S., \& Marshall, P.J. (1985). "Exports, Growth and Causality in Developing Countries" Journal of Development Economics, Vol. 18: 1-12

Levin, A., \& Raut, L.K. (1997) "Complementarities between Exports and Human Capital: Evidence from the SemiIndustrialized Countries" Economic Development and Cultural Change, Vol. 46: 155-174.

Lucas, R. E (.1988). “On the Mechanics of the Economic Development”, Journal of Monetary Economics, 22, pp. 3-42

Michaely, M. (1962). Concentration in International Trade, Amsterdam, North Holland Publishing Company.

Michaely, M. (1977). "Exports and Growth: An Empirical Investigation” Journal of Development Economics, Vol. 4: 49-53

OEC. (2017). Trade statistics on Ghana. Retrieved from https://atlas.media.mit.edu/en/profile/country/gha/

Ram, R. (1985) "Exports and Economic Growth: Some Additional Evidence" Economic Development and Cultural Change, Vol. 33: 415-425.

Ricardo, D. (1817). On the Principles of Political Economy and Taxation. Piero Sraffa (Ed.) Works and Correspondence of David Ricardo, Volume I, Cambridge University Press, 1951, p. 11

Rodrik D, (2006). "What's so special about China's Exports? NBER Working Paper 11947

Sarkar, P. (1986). "The Singer-Prebisch Hypothesis: A Statistical Evaluation”, Cambridge Journal of Economics, Vol. 10 (4): 355-371

Srinivasan, T.N., \& J. Bhagwati. (2001). “Outward Orientation and Development: Are Revisionist Right?” in D. Lai and H. Snape (eds), Trade, Development and Political Economy (Essays in Honor of Anne O. Krueger), New York: Palgrave Publishers

Thirlwall, A.P. (June, 1995). The Terms of Trade, Debt and Development: with Special Reference to Africa, African Development Review.

Trading Economics (2017): Ghana Trade: Retrieved from https:// trading economics.com/ghana/exports World Bank. (2016). Country indicators. Retrieved on from https:// data. worldbank. org/indicator /NY.GDP.MKTP.CD? end $=2016 \&$ locations $=$ GH\&start $=1960 \&$ view $=$ chart 